\title{
Mughal architecture under the cloud of demolition: Environmental effects on monuments
}

Received (in revised form): 13th August, 2008

\begin{abstract}
Adeeba Abdul Raheem
obtained her BSc in Building and Architectural Engineering with honours from UET, Lahore. She served as a lecturer in the same department and is now pursuing her Master's degree in Building construction from the University of Florida, Gainesville, FL, USA. Her major research interest is in Mughal architecture.

\section{Muhammad Akram Tahir}

obtained both his Master's and Doctoral degrees in structural engineering from AIT. Currently, he is serving as Professor and Chairman in the Architectural Engineering \& Design Department at UET, Lahore. Professor Tahir has authored a number of papers on the properties of structural materials. His current research interests include the archaeological and historic heritage of Pakistan, development of low heat and durable concrete and object-oriented software for analysis and design of structures. He is a member of the International Committee on Concrete Model Code for Asia and of the Executive Board of the International Association for Concrete Technology.
\end{abstract}

Correspondence: Adeeba Abdul Raheem, Apartment No. 30, Village 34 Apartments, 328 SW, 34th Street, Gainesville, County of Alachua, FL 32607, USA; Tel: +1 339 226-2284; Fax: +1 352 846-2772; E-mail: adeeba_kas@hotmail.com

\begin{abstract}
Lahore is the city of Mughal heritage in the true sense of the word. Grand buildings with a delicate touch of landscaping express the story of a splendid era of building construction. Some chapters of this monumental architecture have been torn or distorted by subsequent rulers and others are fading away due to the aggressiveness of the environment but still stand as a witness of Mughal grandeur. This paper describes the impact of aggressiveness of the environment on the gradual destruction of the three gems of Mughal architectural treasures: Lahore Fort, Jehangir's tomb and Shalimar Gardens. The main emphasis is on structural damages. Out of the three aforementioned sites, two, the Lahore Fort and Shalimar Gardens, were declared UNESCO World Heritage Sites in 1981, but this status is depleting swiftly due to the ill-planned rehabilitation works funded by UNESCO. This negligence in the refurbishment is aggravating the destruction by environmental agents and these buildings are still struggling with the fate keeping a hope of reappraisal of its past in the form of restoration. Journal of Building Appraisal (2008) 4, 103-114. doi:10.1057/jba.2008.26
\end{abstract}

\section{Keywords:}

Lahore, Mughal heritage, massive structures, lime mortar, environmental factors, deterioration

\section{INTRODUCTION}

Lahore, the capital of Punjab, is a city of undoubted antiquity. Its location has given it a turbulent history full of periodic invasions and pillage. But its beauty and grandeur cannot be exaggerated, because under the reign of the Mughals it rose to the height of splendour. They constructed beautiful edifices and gardens that have surpassed in chastity of radial and bilateral symmetrical design and delicacy of geometric ornamentation.

Mughal architecture is characterised by domes, arches, minarets and vaulted roofs and has no parallel in ornamentation. Massive structural and extremely detailed decorative 


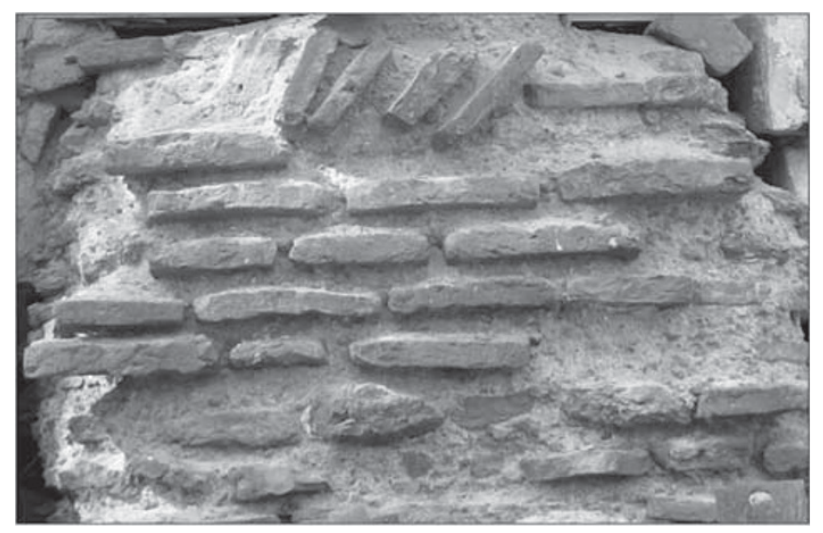

Figure I: Thick layers of lime mortar

artwork placed the Mughals as the greatest contributors to the magnificence of Lahore (Baqir, 1984; Nadeem, 1996). The craft of brick making, laying and cutting was at its apogee. Glazed tiles, red sandstone and white marble were used as veneers over the brick core. The manipulation of geometry and colour resulted in a rich and opulent effect. The white marble with embellishments of mirrors and precious stones expresses the excellent taste of the Mughals. But all this seems to be part of a crushed history due to different destructive agents, and if this should continue, the entire Mughal heritage will just be a part of historical debris.

Every monument of the Mughal era whispers legendry tales of its glorious past. The sustainability of Mughal architecture is characterised by:

(i) Massiveness of the structure, although the basic construction unit is very small: 8 in. $\times 4$ in. $\times 13 / 4$ in.

(ii) Use of rich mortar layered in, with the thickness almost equal to the height of the construction unit (Figure 1).

(iii) Use of nonporous materials for cladding and lining and as the base for platforms.

Environmental dynamics have caused the following damage to the Mughal architectural hulks:

- Decolourising due to the pollutants present in the air: $\mathrm{SO}_{3}, \mathrm{NO}_{3}, \mathrm{CO}_{2}$ and fluorides.

- Chipping of the plaster.

- Development of cracks.

- Deterioration of the structural elements due to weakening of the structural materials (main cause: penetration of water).

- Destruction of ornamental ceiling works due to leakage from the roofs.

\section{CASE STUDIES}

Three masterpieces from the grand Mughal heritage are considered in detail to study the damage and obliteration from different environmental factors. Each of these is meant to serve a different purpose and therefore a comprehensive comparison is carried out among different types of structures, the materials used and the damage caused. 


\section{The buildings}

\section{Lahore Fort}

Lahore Fort is the oldest architectural possession of Lahore, constructed as a fortress to the city on a flat terrain and orientated north-east of the old city. Its history dates back to the conquest of Lahore in the 11th century by Ghaznavi, who, according to historians, laid the foundation of the fort as a mud structure (Khan, 1958; Department of Archaeology and Museums of Pakistan, 1989). After Ghaznavi, the fort served as the victory emblem for many conquerors, but it was protected and developed as a "masterpiece" in true means in the Mughal era. It has witnessed sequential stages of development, starting from the rebuilding of the mud fort with burnt bricks by Akbar and enlargement by Jehangir. It achieved the apex of magnificence through Shah Jahan and then some additions were made by Aurangzeb to contribute to the legacy. There are 21 beautiful edifices added by the Mughals in the fort, but most of them are not in good condition today.

\section{Jehangir's tomb}

Jehangir's tomb is the ultimate resting place of Mughal Emperor Jehangir and was built by Shah Jahan. The building was built in red sandstone with beautiful marble inlay. The ornamentation was enhanced by delicate pietra dura and fresco paintings. Associated with this is the mausoleum of Asif Khan, Jehangir's brother-in-law, which was originally covered with marble and precious stones until it was damaged by the Sikhs.

\section{Shalimar Gardens}

These gardens were laid out by Shah Jahan and are gorgeous examples of proportion and design. Marble platforms and fountains enhance the beauty of the green foliage (Ishtiaq, 2000). The gardens are surrounded by a massive boundary wall whose strength has reduced appreciably through wear and tear over time. Also, the slant of the wall in the lower terrace has increased by several inches.

\section{Building materials}

Field visits to the selected sites portray the true picture of the damage. Structural as well as decorative cladding materials have lost their strength.

\section{Structural materials}

The standard Mughal brick size is 8 in. $\times 4$ in. $\times 13 / 4$ in. with almost 1 in.-thick lime mortar. Rich gypsum plaster was used in Mughal architecture because it also served as a smooth and strong base for the finishes (Figure 2). This plaster was replaced by cement-based plastering material after the Mughal period. Owing to the difference in composition of the original and new plastering material (Cowper, 1927; Ashurst and Ashurst, 1988), the formation of a loose bond was unavoidable and made the chipping process faster.

The mortar consisted of lime, kankar, broken marble or brick pieces and some other additives to improve the different properties of mortar. In Jharoka (Nath, 1986), these additives are described as follows:

- Curd: Dahi used for soft finishing.

- Dal: Urd pulse used as plasticiser.

- San: Jute fibre used for better bonding.

- Gond: Gum from plants used as retarder. 

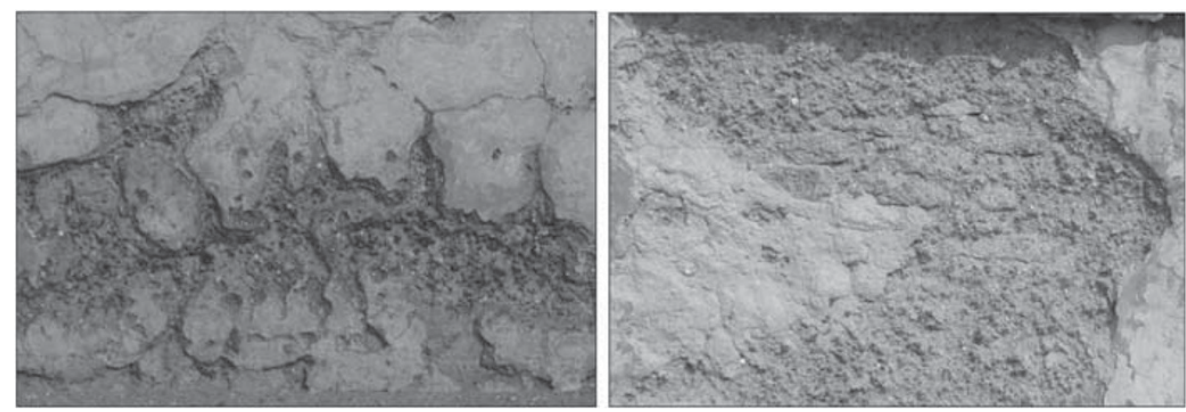

Figure 2: Examples of lime mortar. Lime mortar with original plaster used for the platform in Diwan-eAam (left) and lime mortar with new plastering material in the British period (right)

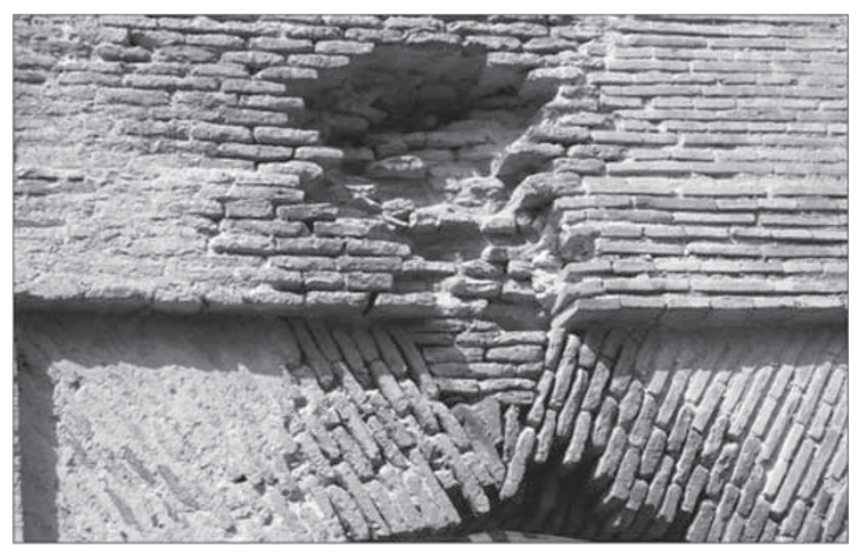

Figure 3: Hollow spaces created in the boundary wall of Shalimar Gardens by deep nicking in mortar

- Gur: Jaggery sugar used for hardening.

- Batashe: Raw sugar used as bonding agent.

- Sirish-i-Kahi: Glue used to increase bond strength.

- Bhus: Straw used for reducing cracks.

Mortar can now be seen tumbling down from the brick courses, forming deeper hollow spaces within the structures (Figure 3). The chipping process has reached such a point that at many places the cross section of columns has reduced to half the original (Figure 4).

\section{Decorative materials}

The main cladding material used during the Akbar and Jehangir periods was red sandstone, but it was supplanted with white marble by Shah Jahan. Red sandstone is a nonporous material with low water absorption properties. Andrew Petersen (1996) presents his observation that red sandstone is strong in compression and, despite its strength and hardness, was carved out with intricate detail in Mughal buildings. Because of these properties it was widely used during the Mughal era, but now it is exposed to the effects of weathering. The natural grains have been revealed due to riving (Figure 5). The new sandstone used in refurbishment work is not of the original type and the differences in natural characteristics can be seen with the naked eye (Figure 6). 


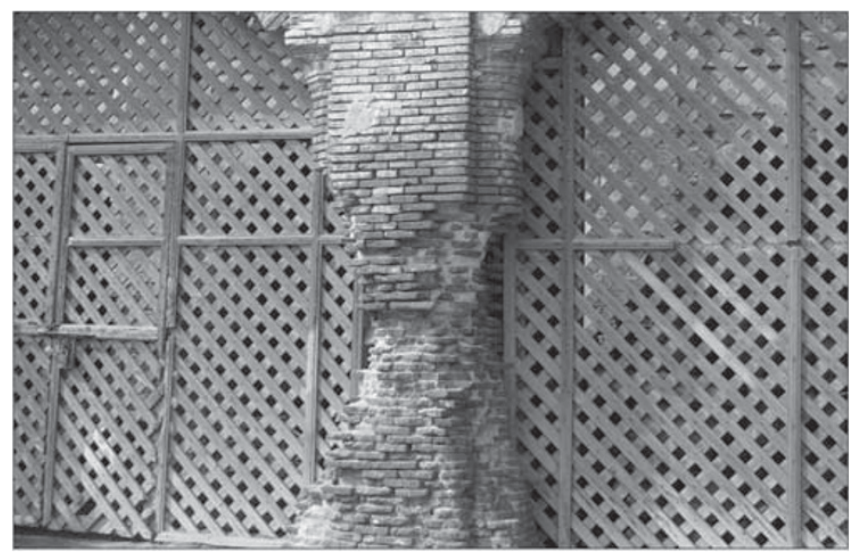

Figure 4: Reduced cross section of a column at Lahore Fort

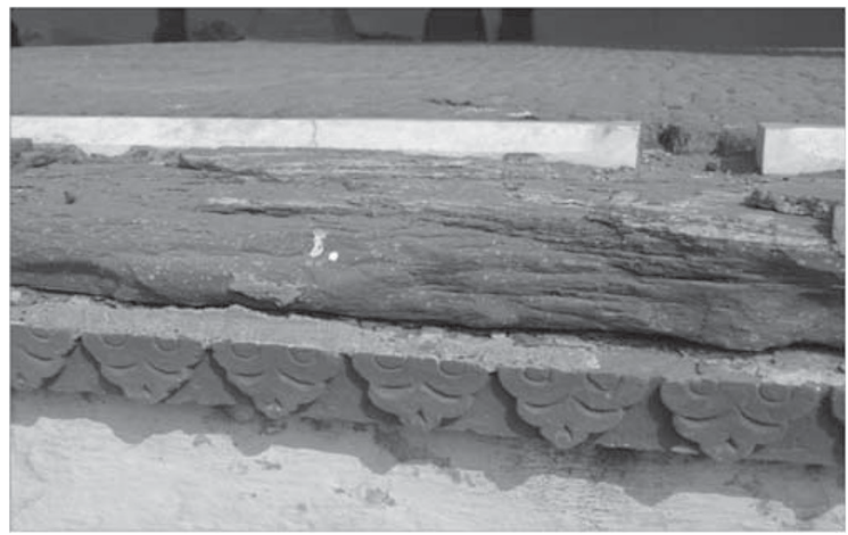

Figure 5: Weathering effects to red sandstone at the base of the platform in Diwan-e-Aam

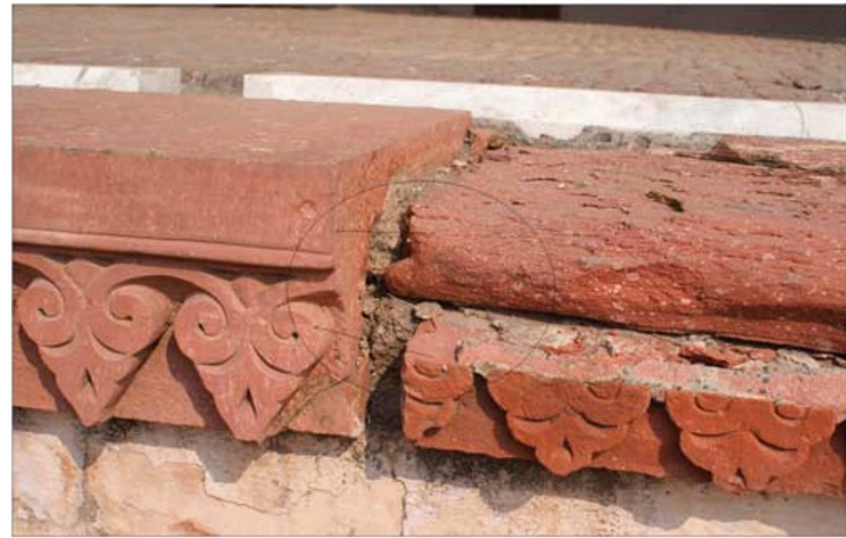

Figure 6: Original (right-hand side) and new (left-hand side) red sandstone material. The difference in colour and grains is visible

The incidence of disjointing of cladding material from the base surface is alarmingly high. At the intersection of cladding materials, the joints have opened even up to $2-3 \mathrm{ft}$ (Figure 7). 

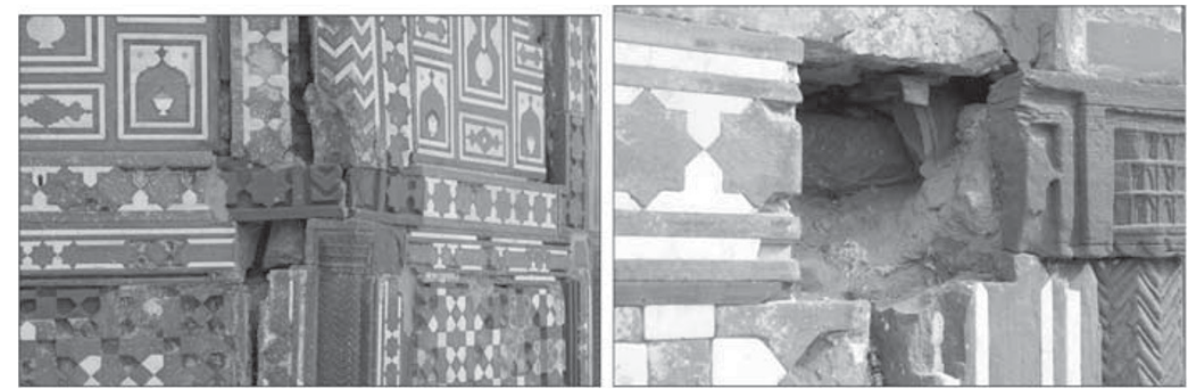

Figure 7: Examples of disjointing, which has caused deep holes in the outer wall of Jehangir's tomb
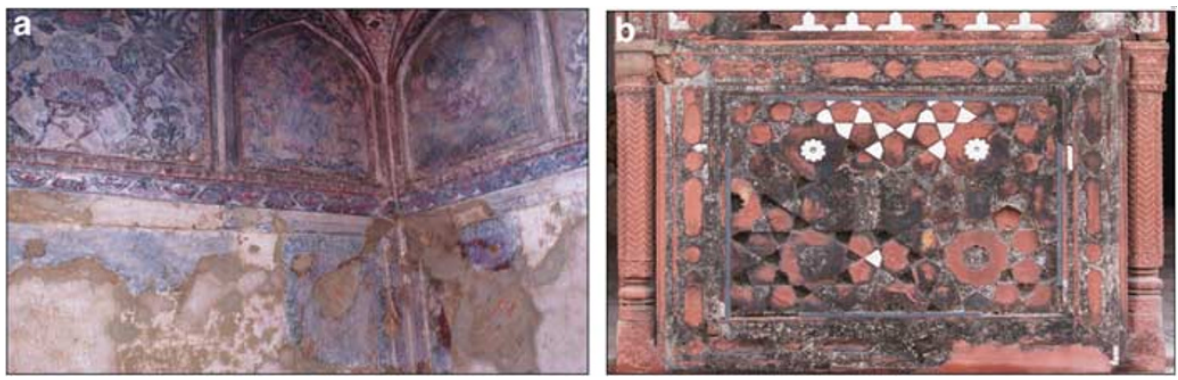

Figure 8: (a) Faded pietra dura work in one of the chambers along the periphery of Jehangir's tomb and (b) decolourised sandstone surface and remaining chunks of marble inlays in a column of the central arch in Jehangir's tomb

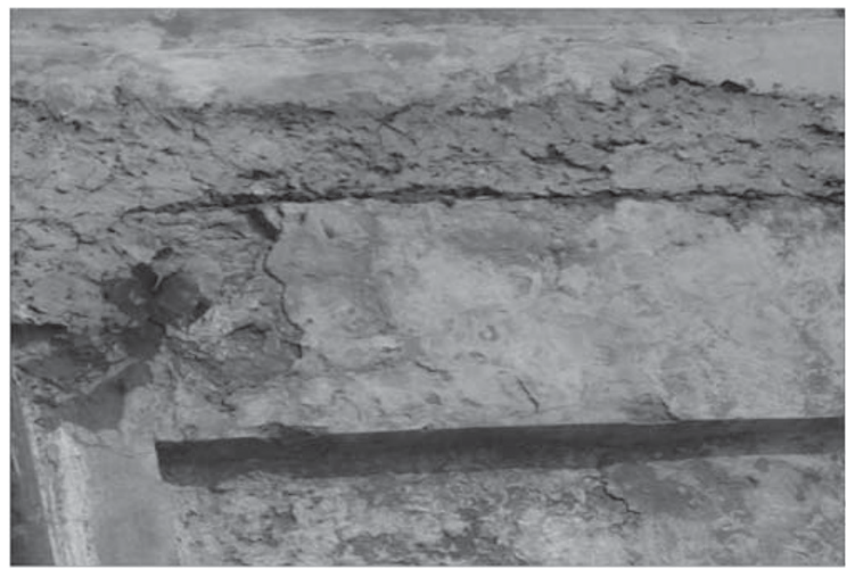

Figure 9: Saline attack on a wall in Lahore Fort

Decolourising due to pollutants is largely visible. The original colours of the pietra dura work have faded away and the marble inlays are crumbling rapidly. The surfaces of all the cladding materials have blackened. Richly carved columns and elaborate brackets in red sandstone have lost their original colour and beauty (Figure 8).

Salt attack is prominent in almost all the buildings. Dissolved salts and gases in the air react with the plastered surfaces and have greatly damaged the facades (Figure 9). The moisture present on the surfaces creates favourable humid environments for different plants to grow and thus weakens the structures with the spread of their roots (Figure 10). 


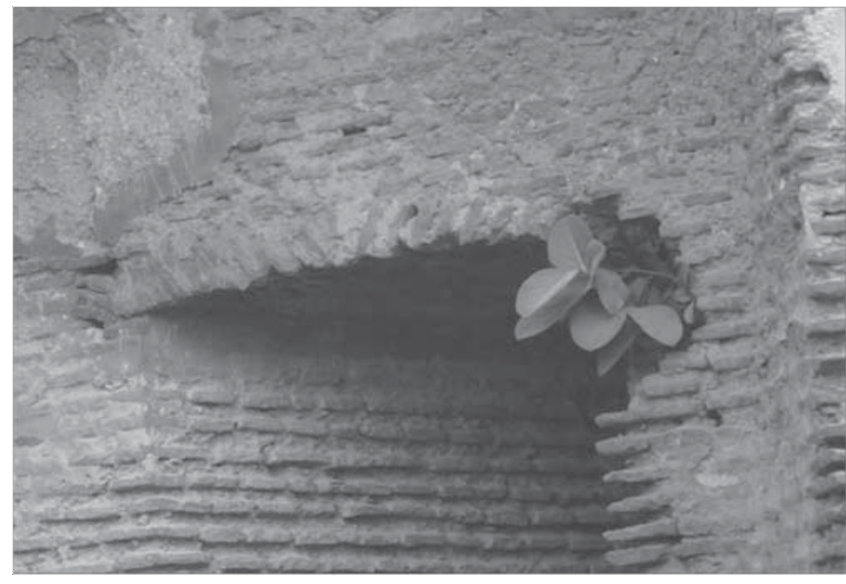

Figure 10: A growing plant at the corner of a brick wall of a cell in caravan sarai at Jehangir's tomb

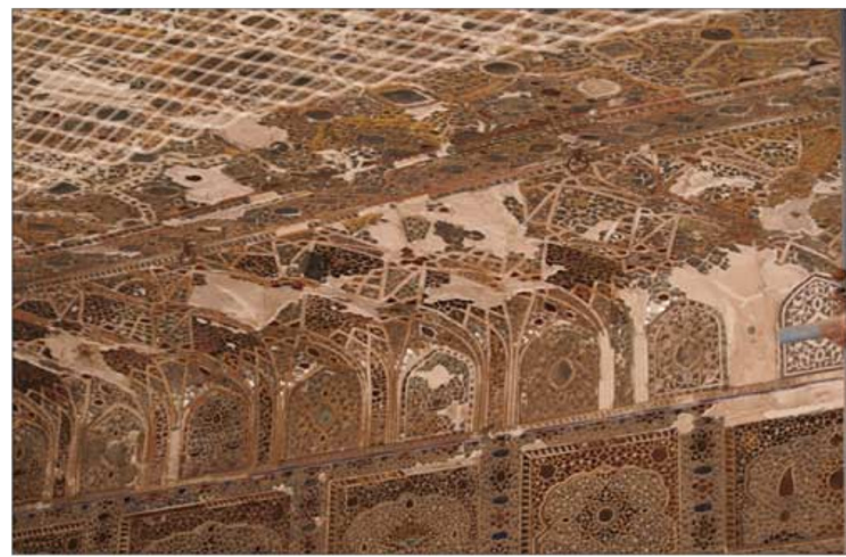

Figure I I: The deteriorating mosaic work of Shish Mahal in Lahore Fort

The mirrors used as decorative materials along with marble in Shah Jahan's period have lost their grace. The pieces of mirrors in the mosaic work have tumbled due to loss of binding strength with the base material (Figure 11) or the transparency has been affected greatly due to different pollutants, particularly dust particles (Figure 12).

\section{Structural damage}

\section{Cracks}

At most of the places cracks in the surface materials have developed and are propagating inside, creating a serious threat to the structural elements (Figure 13). All these cracks are caused by environmental factors, especially rainwater. Plastered surfaces are rare and on most of the surfaces the exposed mortar can be seen. Those on which plaster is present have cracks throughout the surface because of alternate drying and shrinkage. Sandstone used as cladding on the exterior and at the base of the columns is either cracked or has chipped off completely. Owing to the riving process, the sandstone has disintegrated in the form of layers, resulting in a reduced cross section at the base of the columns and the formation of loose joints (Figure 14). 


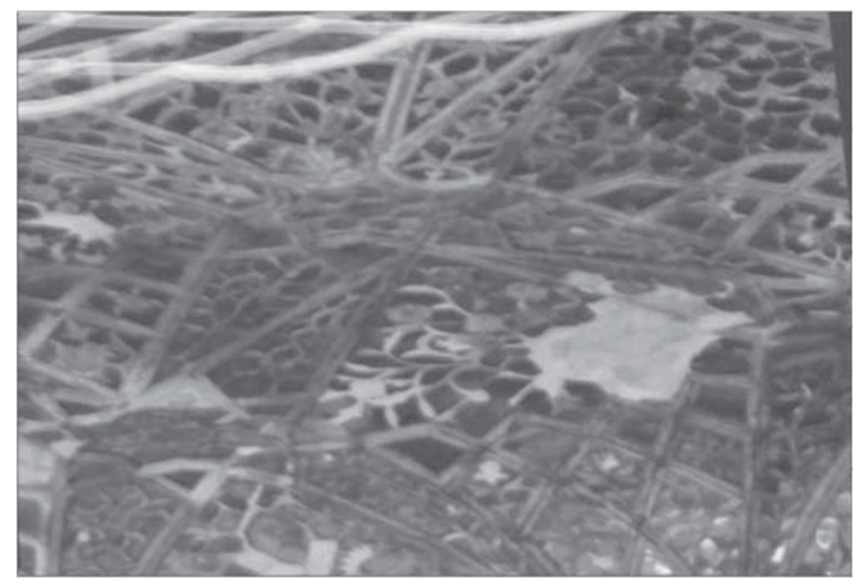

Figure 12: Mirrors used in the mosaic works have lost their shine in Shish Mahal

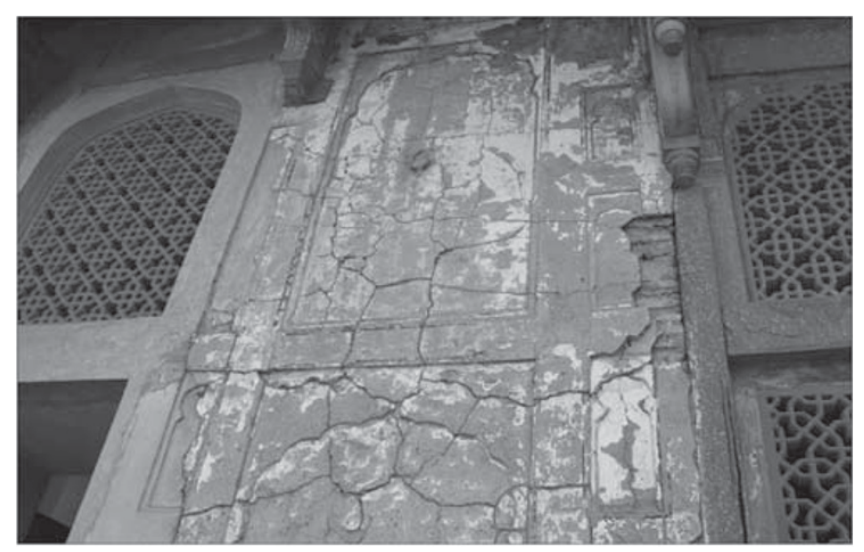

Figure 13: Cracks on the plastered surface at Jehangir's quadrangle, Lahore Fort

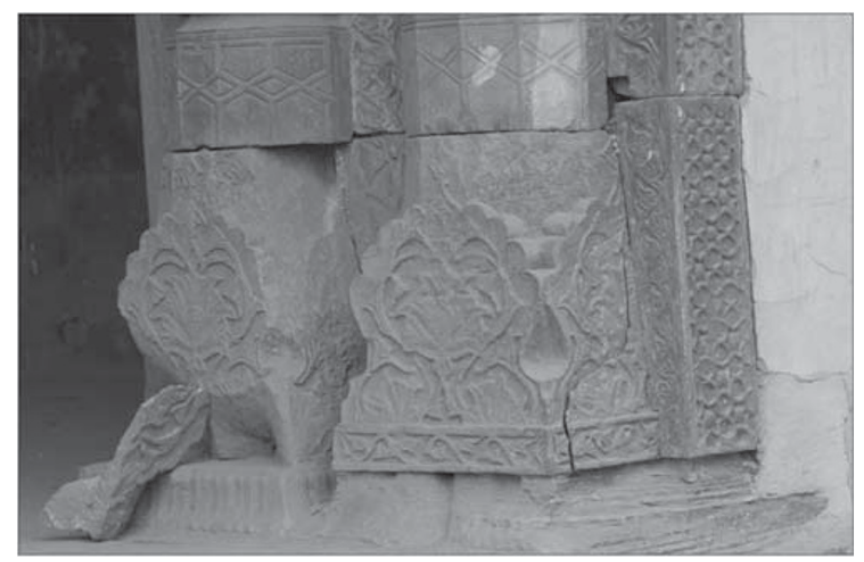

Figure 14: Sandstone cracks on the base of the double columns at Jehangir's quadrangle, Lahore Fort

In most of the buildings, because of accumulation of rainwater on the roof surface, severe cracks have developed, which can be seen at the ceiling level and are propagating at a very high rate (Figure 15). Most of these structural cracks have developed in the maximum bending moment zone and have widened apart up to 1 in. or more (Figure 16). 


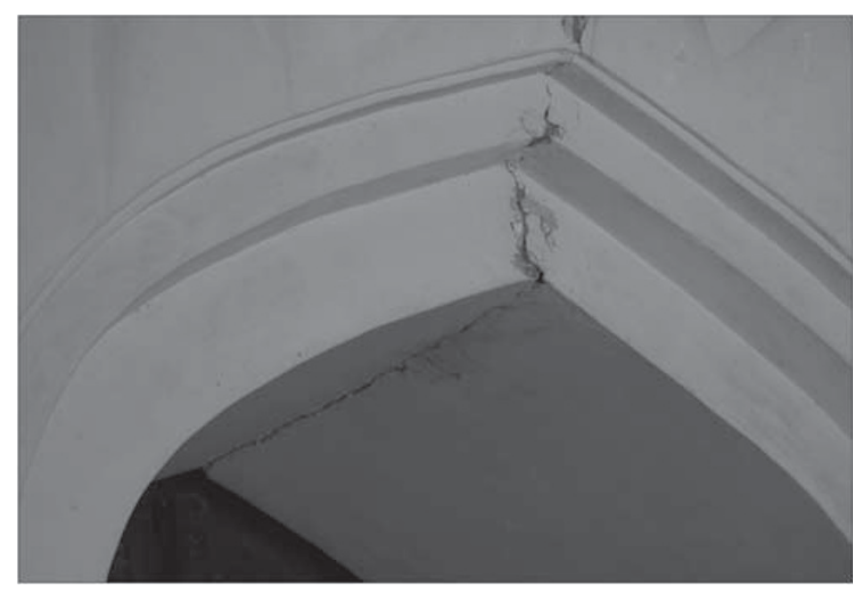

Figure 15: Severe ceiling crack in the central arch of Jehangir's tomb

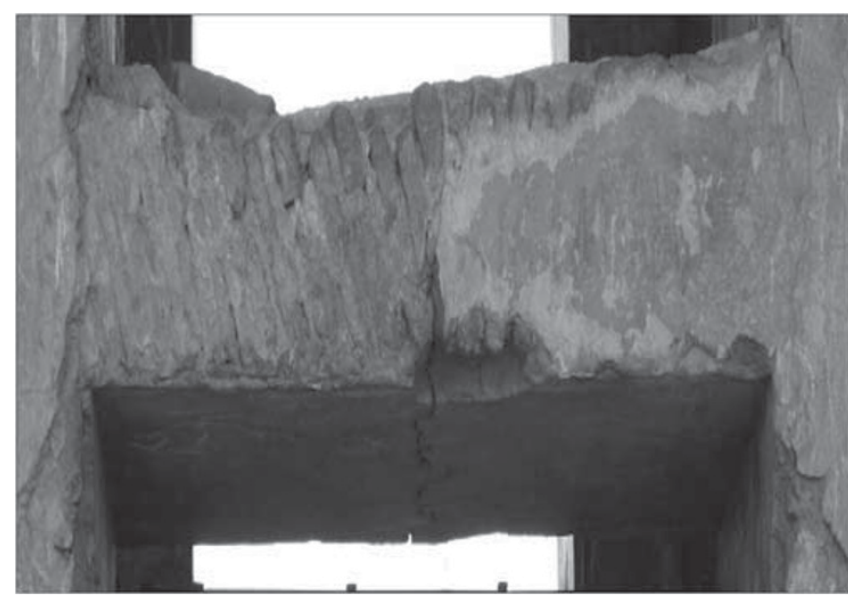

Figure 16: Roof slab about to collapse due to the formation of crack in the middle at Lahore Fort

The width of these cracks is large enough to allow small birds to make nests inside the roofs (Figure 17), while the grooves have widened between floors tiles, transforming the smooth finishes into coarser surfaces (Figure 18). This is most probably due to the temperature gradient between the warmer outer climate and the much cooler inner environment maintained by the massiveness of the structures.

\section{Weakening of structural elements}

In places where plastering material is completely chipped off the mortar is now sliding down from the bricks, and at most of these places the structural elements have lost their strength because of reduced cross sections. This has caused serious damage to the stability of the massive structure supported by these structural elements (Figure 19) and in some places the intensity of this waning is so great that temporary supports are required to hold the structure in place (Figure 20).

Massiveness is one of the prominent features of Mughal architecture. The peripheral walls were constructed up to several feet in width. Owing to continuous wear and tear and 


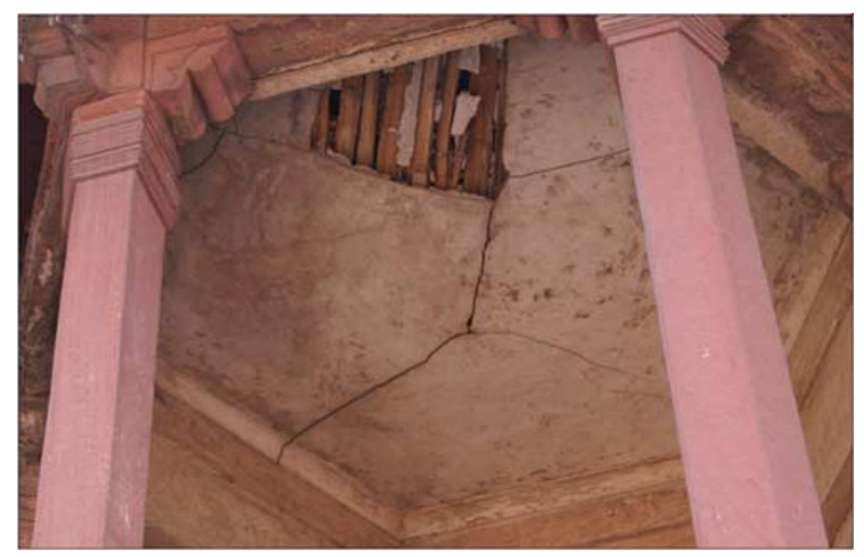

Figure 17: Large ceiling cracks resulting in the chipping of the surface materials, making space birds' nests

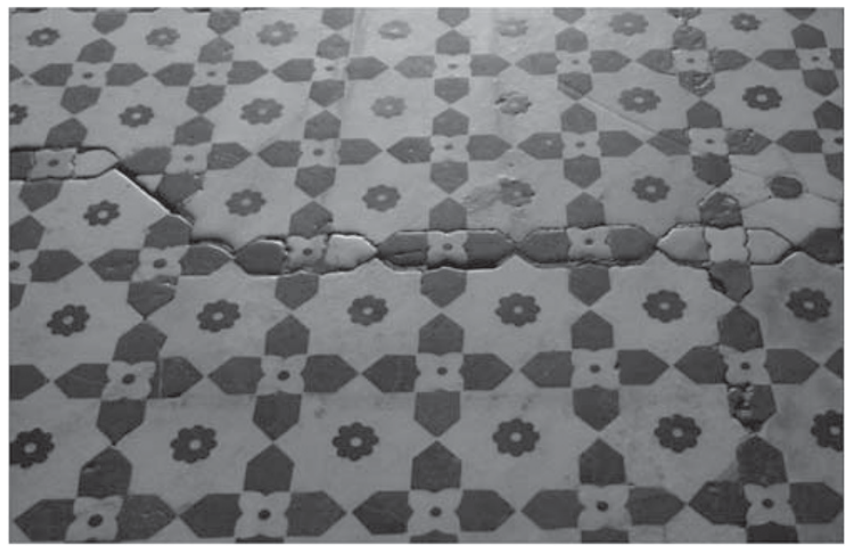

Figure 18: Coarse floor surface in the entrance hall of Jehangir sarcophagus

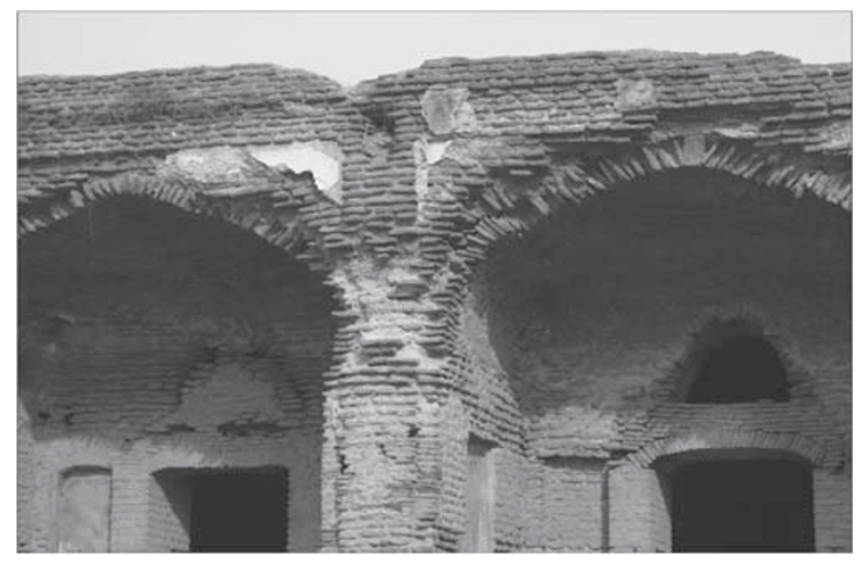

Figure 19: Structural deterioration in the cells of caravan sarai outside Jehangir's mausoleum

negligence in repair works, these boundary walls are in really bad condition and long steep-sided depressions are visible (Figure 21).

The domes and arches on display also highlight the reduced strength of the structures, and most of these have now turned into hollow frames (Figure 22). 


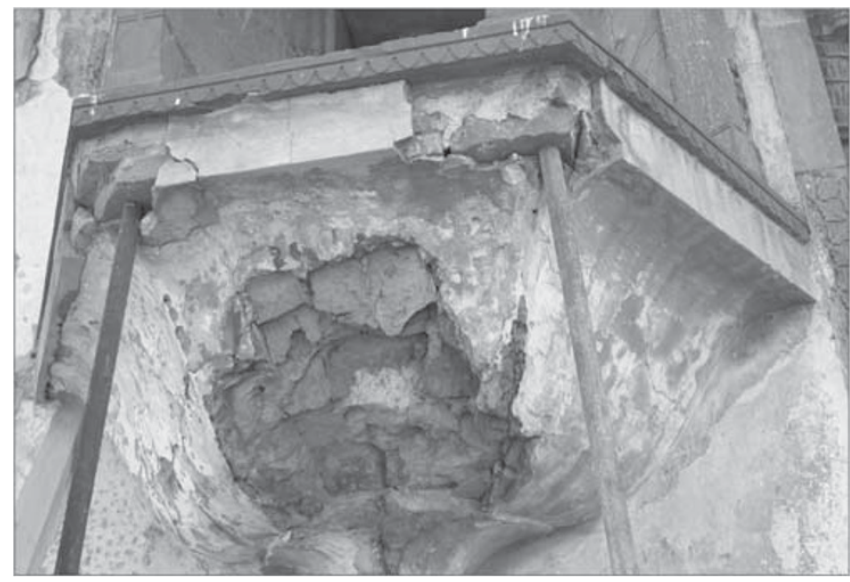

Figure 20: Jharoka supported by steel rods in Lahore Fort
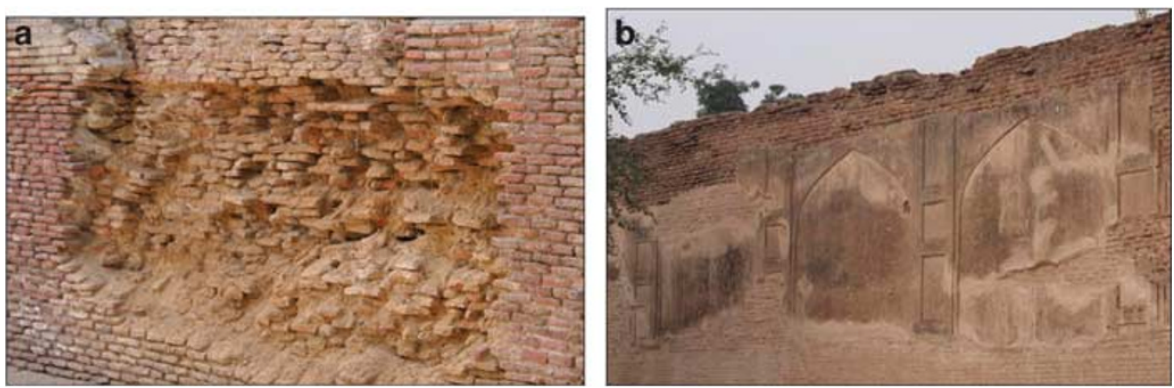

Figure 2 I: Damage to boundary walls: (a) deep recesses creating serious danger to the stability of the boundary wall in Shalimar Gardens and (b) wear and tear of the boundary wall of Jehangir's complex
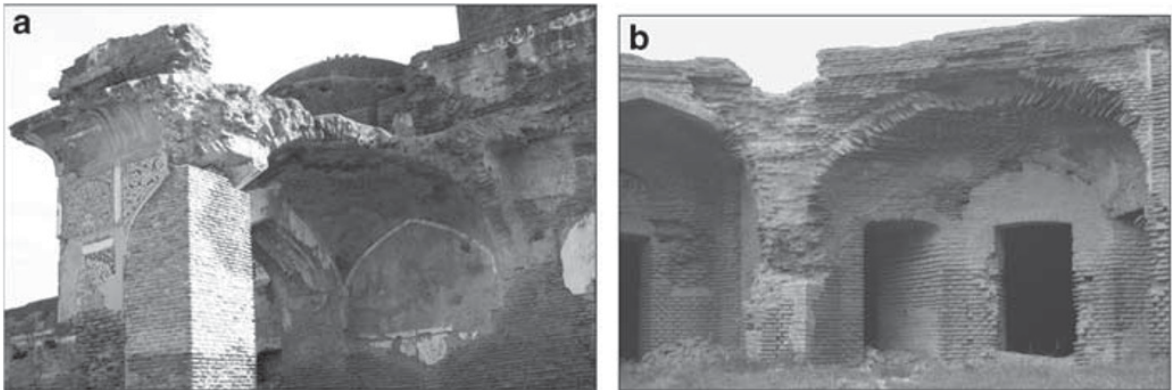

Figure 22: Damage to domes and arches: (a) arch about to fall in the mosque of Jehangir's complex and (b) reduced cross sections of structural members in one of the cells of caravan sarai outside Jehangir's mausoleum

\section{CONCLUSIONS AND RECOMMENDATIONS}

Mughal architecture is on the verge of destruction. Shear negligence in refurbishment work has placed these heirlooms of Mughal history in the race to depletion. Structurally, they have become so weak that just a minor earthquake, a strong shower of rain or a mild flood could now bring these historic buildings to the ground. Environmental factors are playing the role of a catalyst in the destruction, forming hollow slots and deep cracks and 
thus weakening the structures further. Some of the possible solutions to control this destruction process are as follows:

- Salt attack is one of the root causes of deterioration. Salt rises through the water under capillary action. The water table may be lowered by installing sufficient numbers of pumps around the monuments. This is more important in the rainy season when water accumulates around the monuments as a result of poor drainage arrangements.

- In order to protect the buildings from acid attack due to the presence of gases in the atmosphere, plaster of proper composition should be applied to seal the joints/cracks in a decorative way.

- Another reason for rapid deterioration is the nonscientific way of preserving/ strengthening existing structures. The materials used for repair/rehabilitation should be of the same composition as the original materials. Rehabilitation work should be carried out along scientific lines after carefully evaluating the effects of repairing techniques. The interaction of repairing materials with the original construction materials should also be studied in detail before carrying out repair/rehabilitation work.

- The existence of illegal settlements around Jehangir's tomb and Shalimar Gardens is rapidly damaging the decorative boundary walls because of (i) vibration caused by the swift movement of people and vehicles and (ii) seepage from the poor drainage systems of illegal settlements. The government should enforce bylaws to vacate the surrounding premises. The drainage systems in the settlements around these monuments should be made efficient.

- The vibration caused by heavy traffic is damaging Lahore Fort. The frequency of heavy traffic passing on the roads of the Royal Fort should be decreased by diverting the heavy traffic to other nearby roads. Light traffic could be allowed to flow around the fort.

- Local and international awareness of the present condition of these monuments needs to be enhanced.

In conclusion, the systematic urgent assistance of international funding bodies for conservation and of local government is required to save this Mughal architecture before it is lost. Specialists must be engaged in repair work and the use of traditional materials must be encouraged.

\section{References}

Ashurst, J. and Ashurst, N. (1988) Practical Building Conservation, Vol. 3, Mortars, Plasters and Renders, English Heritage Technical Handbook, Gower Technical Press, Aldershot.

Baqir, M. (1984) Lahore, Past and Present (reprint), Punjabi Adabi Academy, Lahore, p. 421.

Cowper, A.D. (1927) Lime and Lime Mortars, Department of Scientific and Industrial Research, Building Research Special Report No. 9, HMSO, London.

Department of Archaeology and Museums of Pakistan. (1989) First Annual Report.

Ishtiaq, M. (2000) World Heritage Sites in Pakistan, United Nations Educational Scientific Cultural Organization Islamabad, Pakistan.

Khan, M. (1958) Lahore and its Important Monuments, Superintendent of Archaeology West Pakistan, Lahore.

Nadeem, I.H. (1996) Lahore - A Glorious Heritage, Sang-e-Meel Publications, Lahore.

Nath, R. (1986) Jharoka, An Illustrated Glossary of Indo-Muslim Architecture, Ajay Nath for HRD Programme Jaipur, India, p. 81.

Petersen, A. (1996) Dictionary of Islamic Architecture, Routledge, UK, p. 200. 